\title{
Monocarboxylate Transporter 1 Inhibitor AZD3965
}

National Cancer Institute

\section{Source}

National Cancer Institute. Monocarboxylate Transporter 1 Inhibitor AZD3965. NCI

Thesaurus. Code C105399.

An orally available inhibitor of monocarboxylate transporter 1 (MCT 1), with potential antineoplastic activity. Upon oral administration, MCT 1 inhibitor AZD3965 binds to MCT 1 and prevents the transport of lactate into and out of the cell. This leads to an accumulation of lactate, intracellular acidification, and eventually cancer cell death. MCT 1, a protein overexpressed on tumor cells, is responsible for the transport of monocarboxylates across the cell membrane and plays a key role in cell metabolism. 